\title{
官能評価による生ハムの食感品質と購買評価に関する研究
}

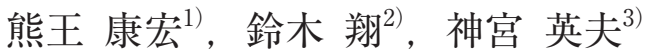 \\ ${ }^{(1)}$ 米久株式会社, ${ }^{2)}$ 金沢工業大学大学院システム設計工学, ${ }^{3)}$ 金沢工業大学)
}

\section{A study of eating quality and purchasing evaluation of raw ham by sensory evaluation}

\author{
Yasuhiro Kumaor ${ }^{1)}$, Syou Suzuki ${ }^{2}$, Hideo Jingu ${ }^{3)}$ \\ ${ }^{1)}$ Yonekyu Corporation, 1259 Okanomiyaterabayashi, Numazu-shi, Shizuoka \\ ${ }^{2)}$ Graduate School of System Design Engineering, Kanazawa Institute of Technology, 7-1, \\ Ohgigaoka, Nonoichimachi, Ishikawa-gun, Ishikawa-ken \\ ${ }^{3)}$ Kanazawa Institute of Technology, 7-1, Ohgigaoka, Nonoichimachi, Ishikawa-gun, Ishikawa-ken
}

\begin{abstract}
The relation among evaluations in eating quality affects one's "desire to purchase", "sense of safety", and "sense of well-being". The purpose of this study was to clarity the relation among evaluations of the eating quality of raw ham, as well as to determine how the relation influences one's "desire to purchase", "sense of safety", and "sense of well-being." In this study, the samples were four raw hams which were very similar in terms of chemical composition, texture, and price. The result of principle component analysis indicated the importance of the "general evaluation by 'umami' and good texture" and "a moist texture as judged by the degree of saltiness" of the ham. The result of discriminant analysis indicated that the "general evaluation by "umami' and good texture" affected one's "desire to purchase" and "sense of safety", and the "moist texture as judged by the degree of the saltiness" affected the "sense of well-being." In other words, the relation among evaluations of eating quality was affected by the purchasing evaluations.
\end{abstract}

(Received 31 August, Accepted 23 September 2010)

Keywords: raw ham 生八ム, sensory evaluation 官能評価, principle component analysis 主成分分析, discriminant analysis 判別分析, eating quality 食感品質

\section{1. 緒言}

食品の“安心感”，“健康感”は，偽装などの社会的 な問題によって, 多くの人々から疑問視されている.

人は, 食品のパッケージに揭載された成分表示を見て, その安全性を確認し購入している. 成分表示に示され た内容により食品の安全性は認識できるが, 食品を食 べたときの “安心感”, “健康感”は, 食品のパッケー ジに掲載された成分表示からは確認しにくく, 企業は, 様々な偽装問題に対する方策として, コンプライアン スを重要視している. コンプライアンスとは, 法令順 守を強く意味しており, 食品会社での遵守すべき法令
としては, 主に食品衛生法と景品表示法がある。これ らの法令を守るために, 食品会社では企業の社会的責 任 (CSR : Corporate Social Responsibility) のもとで 行動基準を定めている. 食品会社の行動基準には, 景 品表示法を意識した定まりが基本的項目として設けら れ, 誇大表示せずに中身の印象を的確に表現する必要 性が説かれている.

一般的に, “もの” の総合評価は物理的・化学的特 性に直結した個別評価によって規定されており, 評価 の階層性が存在している，食品に対する“おいしさ”, “食べたさ”などの総合評価は, 評価の階層性でも上 
位評価となり，“塩っぽさ”などの評価は個別評価と なる，人が，食品を評価する場合，様々な情報が影響 している．過去の経験や時代の風潮などの外的情報が 食品の評価に影響し, 複雑な評価間の相互関係が存在 していると考えられ，これは食感品質 (Eating Quality）と捉えることができる（熊王，2005)。外的 情報として代表的なパッケージは，食感品質上の評価 の関係性によって影響を受けており，官能評価を用い ることで，中身の印象を的確に表現し，品質構成に適 合したパッケージデザインを設計することが可能と なった（藤田, 熊王, 神宮, 2006).

食感品質上の評価の関係性は, 購入するときの評価 となる“買いたさ”, “安心感”, “健康感”に大きな影 響を与えていると思われる。つまり，“買いたさ”，” 安心感”, “健康感” といった購入するときの評価は, 成分表示では確認できない重要な購買行動に直結する 評価であり，食品を食べて強調される，いわば 購買 評価”の主軸として捉えることができる.

食感品質上の評価の関係性を明らかにすることで, 食品の特徵を特定することができ, 食品の品質構成に 反映させることで製造工程を特定でき, “よりおいし い”, “より食べたい”と感じる食品になる（熊王, 神 宮，2003）。しかし，主成分分析により特定できた食 品の特徵が, 購入評価に影響する特徴かどうかを判断 することは困難である。企業における CSR 活動の目 的は, 「企業の持続的発展」であり, 食品会社として は, 官能評価により特徵として明らかにできた評価の 関係性が, 購買評価に対してどのように影響している のかを判断する必要がある.

本研究の目的は, 生ハムの官能評価によって得られ た結果から，食感品質上の評価の関倸性を明らかにし， さらに, これらの関係性が, “買いたさ”, “安心感”, “健康感”に対してどのように影響しているのかを判 断することである.

\section{2. 実験方法}

評価の方法は，5段階評価尺度を用いた。評価項目 は, 生八ムの食感品質に関係する評価調査を予め実施 し, 調査結果から 15 項目を選定した。これらの食感 品質に関する評価を回答してもらった後で, 購買評価 である「買いたさ」,「安心感」,「健康感」に関しては, 「感じる」，あるいは「感じない」を格付けしてもらっ た。

本研究で用いるサンプルは, 物理的・化学的特性に
変化がほとんど見られず，価格帯も同一の商品でなけ ればならない。この条件に該当する商品としては, 生 八ムが考えられるため, 本研究のサンプルとして, 市 販品の生ハム 4 種類（A， B， C， D）を用いた.

開封直後, パネルに食べてもらい, 所定の評価用紙 に感じた度合いを評価してもらい，「買いたさ」，「安 心感」,「健康感」を感じるかどうか回答してもらった パネルは, 20 歳代前半の大学生 33 名（男性 23 名, 女性 10 名）である.

パネルには，それぞれ 1 枚ずつのサンプルを食べて もらい, どの程度感じたのかを評価してもらった．評 価尺度とその得点は,「感じない」(1),「あまり感じ ない」(2),「やや感じる」(3),「かなり感じる」(4), 「とても感じる」（5）の 5 段階評価尺度を用いた。 ま た，パネルに先入観を持たせないために, サンプルや 実験に関する情報は実験後も含めて与えなかった。

各サンプルの物理的, 化学的特性に差がある場合, 官能評価の結果も大きく異なることが考えられる，生 八厶の場合, 各社の厚みは一定であり, 物理的特性の 計測は必要としない. 各サンプルが, 化学的にどの程 度相違しているのかを把握するために, 生八ムの基本 的な化学的試験の項目である塩分, 水分活性を計測し た。

\section{3. 結果と考察}

\section{1 物理的 - 化学的試験}

各サンプルにおける塩分濃度と水分活性を計測した。 その結果, 各サンプルの塩分濃度と水分活性に大きな 違いは見られなかった（Table 1)。この結果は, 各サ ンプルが，ほとんど同一のものであることを意味して いる.

\section{2 平均值とその $95 \%$ 信頼区間}

各サンプルの評価項目について, 評価の平均值とそ の 95\%信頼区間を算出した (Figure 1，2，3，4）。 こ れは, 100 回同様の官能評価実験を実施しても, 95 回 は上限值と下限值の間を平均值が推移することを意味

Table 1 各サンプルの塩分と水分活性

\begin{tabular}{|c|r|r|}
\hline サンプル & 塩分(\%) & \multicolumn{1}{|c|}{ 水分活性 } \\
\hline $\mathrm{A}$ & 4.55 & 0.94 \\
\hline $\mathrm{B}$ & 4.85 & 0.94 \\
\hline $\mathrm{C}$ & 4.69 & 0.94 \\
\hline $\mathrm{D}$ & 4.71 & 0.93 \\
\hline
\end{tabular}




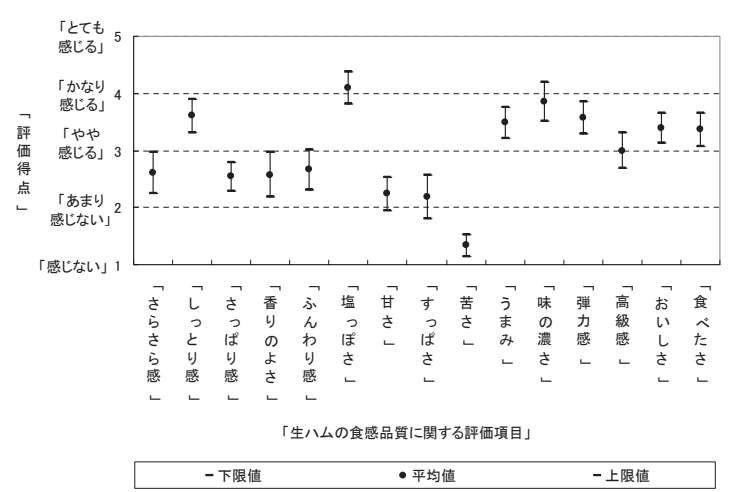

Figure 1 平均値とその 95\%信頼区間（サンプル A)

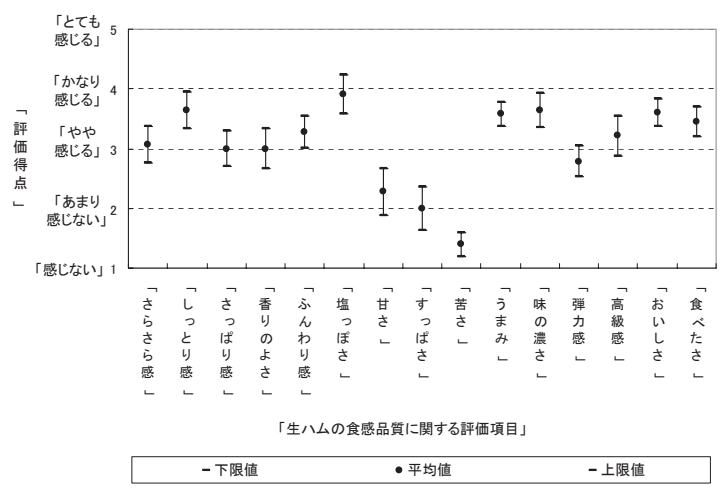

Figure 3 平均値とその $95 \%$ 信頼区間（サンプル C)

している. 各サンプルの評価の平均值とその $95 \%$ 信 頼区間を算出した結果，各サンプルの評価項目間に有 意差は見られなかった。

各社の生八ムは,「塩っぽさ」をかなり感じ,「苦 さ」を感じないという評価であった.

サンプルとした生八ムは, 食感品質上の評価の関係 性が存在していると考えられえるため, 官能評価の結 果を主成分分析により分析した.

\section{3 主成分分析}

主成分分析の結果，固有値は 1.0 以上で 5 主成分抽 出され,このときの累積寄与率は $62.6 \%$ であった (Table 2). 各評価項目において, 主成分負荷行列の 絶対值の最大を確認し, 各主成分を解釈した。

主成分 1 は,「さらさら感」,「さっぱり感」,「うま み」,「高級感」,「おいしさ」,「食べたさ」の評価項目 から構成されており，総合評価となる「高級感」，「お いしさ」，「食べたさ」が主成分 1 の構造の中に含まれ ていた，したがって，「うまみと舌触りの良さによる

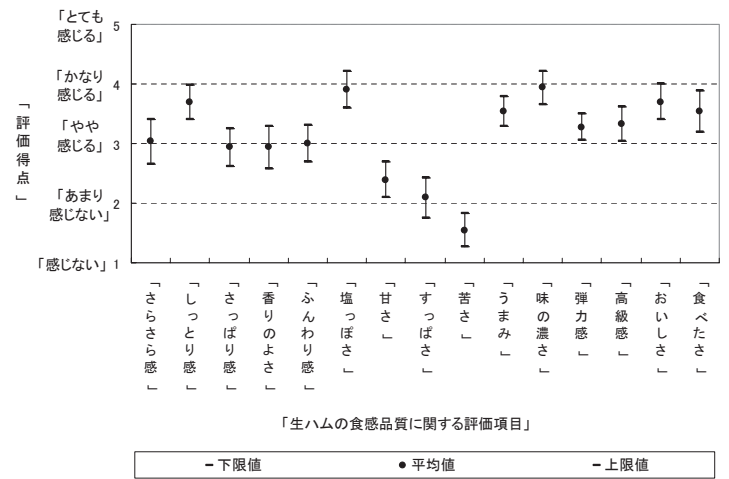

Figure 2 平均值とその 95\%信頼区間（サンプル B)

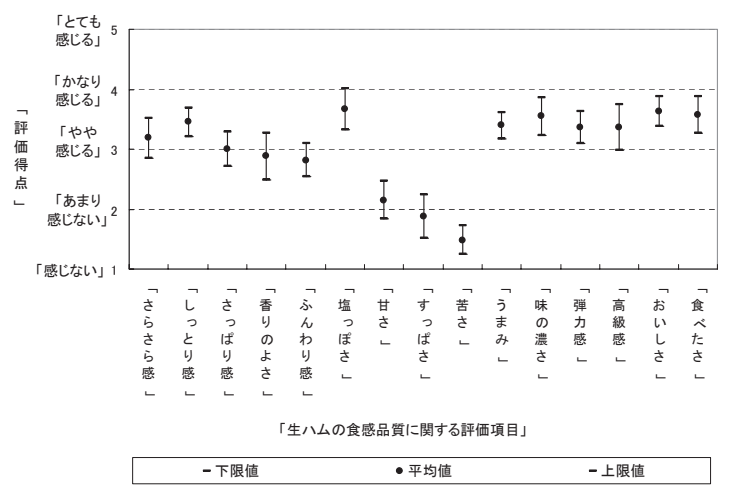

Figure 4 平均值とその 95\%信頼区間（サンプル D）

総合評価」と解釈できる，生八ムを製造する際に，香 辛料などをすり込み，低温で貯蔵することからも，こ のような特徴になったと考えられる. 生八厶の「高級 感」,「扔いしさ」,「食べたさ」は,「さらさら感」, 「さっぱり感」,「うまみ」により左右される可能性が ある。

主成分 2 は,「しっとり感」,「塩っぽさ」,「味の濃 さ」の評価項目から構成されており,「塩味の濃さに よるしっとり感」と解釈できる，生八ムは，塩水に漬 け込むことからも, 塩の濃度が肉の「しっとり感」と いう評価に影響していると考えられる。

主成分 3 は,「甘さ」,「すっぱさ」,「苦さ」から 「甘酸っぱさと苦さ」と解釈できる，生八厶の原料と なる豚肉の甘酸っぱさと製造工程で用いられる殺菌用 アルコールが影響している可能性がある.

主成分 4 は,「弾力感」と解釈できた。

主成分 5 は「香りのよさ」と「ふんわり感」から 「香りによるふんわり感」と解釈できる。 
官能評価による生ハムの食感品質と購買評価に関する研究

Table 2 主成分分析の結果（主成分負荷行列, 固有值, 寄与率, 累積寄与率)

\begin{tabular}{|c|c|c|c|c|c|}
\hline 評価項目 & $\begin{array}{c}\text { 主成分 } 1 \\
\text { 「うまみと } \\
\text { 舌触りの良さ } \\
\text { による総合評価」 }\end{array}$ & $\begin{array}{c}\text { 主成分 } 2 \\
\text { 「塩味の濃さによる } \\
\text { しっとり感」 }\end{array}$ & $\begin{array}{c}\text { 主成分 } 3 \\
\text { 「甘酸つぱさと } \\
\text { 苦さ」 }\end{array}$ & $\begin{array}{l}\text { 主成分 } 4 \\
\text { 「弾力感」 }\end{array}$ & $\begin{array}{l}\text { 主成分 } 5 \\
\text { 「香りによる } \\
\text { ふんわり感」 }\end{array}$ \\
\hline 「おいしさ」 & 0.874 & -0.024 & 0.005 & 0.138 & -0.223 \\
\hline 「食べたさ」 & 0.857 & -0.027 & -0.040 & 0.129 & -0.295 \\
\hline 「高級感」 & 0.752 & 0.227 & 0.119 & 0.241 & -0.020 \\
\hline 「うまみ」 & 0.621 & 0.190 & 0.114 & -0.202 & -0.378 \\
\hline 「さっぱり感」 & 0.478 & -0.388 & 0.012 & -0.346 & 0.280 \\
\hline 「さらさら感」 & 0.473 & -0.081 & -0.152 & -0.301 & 0.407 \\
\hline 「塩っぽさ」 & -0.118 & 0.825 & 0.156 & -0.139 & -0.002 \\
\hline 「味の濃さ」 & -0.129 & 0.816 & 0.201 & -0.113 & -0.149 \\
\hline 「しっとり感」 & 0.222 & 0.522 & -0.092 & -0.391 & 0.279 \\
\hline 「苦さ」 & -0.228 & -0.076 & 0.746 & 0.104 & 0.167 \\
\hline 「すっぱさ」 & -0.040 & -0.105 & 0.716 & -0.239 & -0.207 \\
\hline 「甘さ」 & 0.208 & -0.210 & 0.615 & 0.238 & 0.190 \\
\hline 「弾力感」 & -0.005 & 0.364 & -0.144 & 0.706 & 0.198 \\
\hline 「香りのよさ」 & 0.277 & 0.336 & 0.039 & 0.056 & 0.431 \\
\hline 「ふんわり感」 & 0.380 & -0.011 & 0.158 & 0.076 & 0.425 \\
\hline 固有値 & 3.300 & 2.172 & 1.620 & 1.161 & 1.137 \\
\hline 寄与率(\%) & 22.0 & 14.5 & 10.8 & 7.7 & 7.6 \\
\hline 累積寄与率(\%) & 22.0 & 36.5 & 47.3 & 55.0 & 62.6 \\
\hline
\end{tabular}

このように解釈できた生ハムの各サンプルが, どの 程度, 評価されているのかを確認するために, 算出さ れた主成分得点の平均值を散布図上に布置した。この 散布図は，横軸を主成分 1 , 縦軸を主成分 2 として作 成した（Figure 5).

Figure 5 からも,「サンプル A」は他のサンプルと 比較し, 主成分 1 上での評価は低く，主成分 2 上では 高く評価されていた。「サンプル A」は，主成分 1 で ある「うまみと舌触りの良さによる総合評価」を向上 させるために, 生八ム製造時に用いる香辛料と貯蔵す る期間を見直し，主成分 2 である「塩味の濃さによる しっとり感」を低下させるために，塩分濃度を調整す る必要がある.

\section{4 判別分析}

主成分分析により得られた結果では, 食感品質上の 評価の関係性は明らかにでき, 各サンプルがどの程度, 評価されているのかを確認できた。しかし，生ハムに おける食感品質上の評価の関係性が, どの程度, 購買

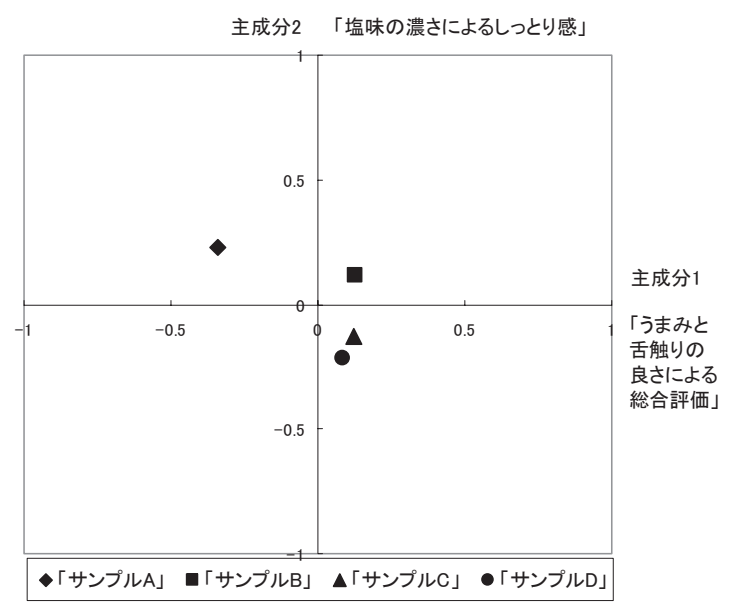

Figure 5 主成分得点の平均の散布図(主成分 1 , 主成分 2)

評価に影響する特徵となっているのかを判断する必要 がある。そこで，主成分分析で算出した主成分得点と 
Table 3 主成分得点の判別分析結果

\begin{tabular}{|c|r|r|r|r|r|r|}
\cline { 2 - 7 } \multicolumn{1}{c|}{} & \multicolumn{2}{c|}{ 「買いたい」 } & \multicolumn{2}{c|}{ 「安心感」 } & \multicolumn{2}{c|}{ 「健康感」 } \\
\cline { 2 - 7 } \multicolumn{1}{c|}{} & 判別係数 & \multicolumn{1}{c|}{$\mathrm{F}$ 比 } & 判別係数 & \multicolumn{1}{c|}{$\mathrm{F}$ 比 } & 判別係数 & \multicolumn{1}{c|}{$\mathrm{F}$ 比 } \\
\hline 定数 & -0.588 & & -0.31 & & 0.13 & \\
\hline 主成分 1 & -1.942 & 63.408 & -1.393 & 39.524 & -0.547 & 7.256 \\
\hline 主成分 2 & 0.117 & 0.231 & 0.391 & 3.121 & 0.871 & 18.427 \\
\hline 主成分 3 & -0.077 & 0.1 & -0.084 & 0.143 & -0.107 & 0.279 \\
\hline 主成分 4 & 0.334 & 1.88 & -0.303 & 1.866 & -0.395 & 3.787 \\
\hline 主成分 5 & -0.015 & 0.004 & 0.086 & 0.15 & 0.132 & 0.422 \\
\hline
\end{tabular}

購買評価となる「買いたさ」,「安心感」,「健康感」を 判別分析した（Table 3).

「買いたさ」,「安心感」には主成分 1 である「うま みと舌触りの良さによる総合評価」が大きく影響して いた.「買いたさ」，「安心感」の主成分 1 の F 比が非 常に大きいことからも，主成分 1 である「うまみと舌 触りの良さによる総合評価」の得点を向上させること で,「買いたさ」,「安心感」がより感じる商品となる. 「健康感」には，主成分 2 である「塩味の濃さによる しっとり感」が大きく影響していた。

主成分得点を判別分析した結果, 購買評価によって は，影響をもたらす食感品質上の評価の関係性が異 なっていた。

\section{4. 結言}

大学生をパネルとして用いた調查方式を一般のパネ
ルに拡張することで, 食品の安全性に対する評価を予 測，保証できるものと考える。したがって，広く一般 のパネルを用いた調查でも, 十分な有効性をもつ調査 法であることを検証することは, 今後の課題となる.

生ハムの官能評価によって得られた結果を主成分分 析することで, 食感品質上の評価の関係性を明らかに し, 品質構成に直結したリニューアルポイントを明ら かにすることが可能となった，さらに，主成分得点を 判別分析することで, 影響をもたらす評価の関係性が どの購買評価に影響をもたらしているのかを判断でき た. その結果, 購買評価に基づくリニューアルポイン トとして,「より買いたい」,「より安心感のある」, 「より健康感のある」商品を実現するための手法を提 案できた。

\section{引用文献}

藤田佳典, 熊王康宏, 神宮英夫 : 食品のパッケージが 品質の評価に及ぼす影響, 人間生活工学第 7 巻第 4 号, 34-39, 2006

熊王康宏 : 径の大きさに基づく食感品質の感性評価, 感性工学研究論文集, 第 6 巻 1 号, 73-78, 2005 熊王康宏, 神宮英夫 : 感性評価によるローストビーフ の匂い設計に関する研究, 日本味と匂学会誌, 第 10 巻 3 号, 789-792, 2003 